\title{
A EXCLUSÃO SOCIAL DO IDOSO NO AMBIENTE URBANO
}

\section{THE SOCIAL EXCLUSION OF THE ELDERLY IN THE URBAN ENVIRONMENT}

\author{
Mateus de Oliveira Fornasier ${ }^{1}$ \\ Flavia Piva Almeida Leite ${ }^{2}$
}

\section{Resumo}

Estuda-se a exclusão social do idoso do ambiente urbano - principalmente no que tange à obliteração dos seus direitos de ir e vir e de participar da vida em comunidade. Apresenta fatores histórico-filosóficos e científicos acerca de quem é o idoso e de como este é considerado excluído da sociedade. Também observa a exclusão do idoso do ambiente urbano, com dados científicos acerca de fatores de exclusão no mundo e no Brasil, exemplificando-se, também, de que forma o prejuízo na mobilidade urbana da terceira idade é um fator incrementador de sua exclusão decorrente do próprio envelhecimento biológico. Conclui-se que os sistemas funcionais pressupõem a inclusão de todos os seres humanos, mas de fato, excluem pessoas que não preenchem seus requisitos, e um tipo de exclusão serve de fundamento para os demais. Ademais, não é a busca por um responsável pela exclusão, mas sim, a análise de que se trata de um complexo de responsabilidades, é o que deve embasar políticas públicas de inclusão da pessoa idosa no ambiente urbano. Metodologia: método de pesquisa sistêmico-construtivista, com abordagem qualitativa e técnica de pesquisa bibliográfica.

Palavras-chave: Ambiente Urbano; Exclusão; Idoso.

\begin{abstract}
The social exclusion of the elderly from the urban environment is studied - especially as regards the obliteration of their mobility rights and to participate in community life. It presents historical-philosophical and scientific factors about who the elderly are and how they are considered excluded from society. It also observer the exclusion of the elderly from the urban environment, with scientific data about exclusion factors in the world and in Brazil, also showing how the impairment in the urban mobility of the elderly is an increasing factor of their exclusion due to the biological aging. We conclude that urbanization must be understood as an event directly linked to globalization: not only space and urban interactions are achieved, but social relations in the countryside are also organized towards the urban center. In addition, functional systems presuppose the inclusion of all human beings, but in fact, exclude people who do not meet their requirements, and one type of exclusion serves as a foundation for others. Finally, it is not the search for an only responsible for exclusion, but rather the analysis that it is a complex of responsibilities, that is what should support public policies for inclusion of the elderly in the

\footnotetext{
1 Doutor em Direito Público pela Universidade do Vale do Rio dos Sinos (UNISINOS). Professor do Mestrado em Direitos Humanos da Universidade Regional do Noroeste do Estado do Rio Grande do Sul (UNIJUÍ). E-mail: mateus.fornasier@gmail.com

2 Professora da Faculdade de Arquitetura, Artes e Comunicação - no Departamento de Ciências Humanas da FAAC/UNESP. Professora do Programa de Mestrado em Direito da UNESP/Franca. Doutora em Direito do Estado pela PUC/SP. E-mail: flaviaaleite3@hotmail.com
} 
urban environment. Methodology: systemic-constructivist research method, with a qualitative approach and bibliographical research technique.

Keywords: Urban Environment; Exclusion; Elderly.

\section{INTRODUÇÃO}

O envelhecimento não é um fenômeno novo. Afinal, pela lógica natural da existência, os homens nascem, crescem, amadurecem e morrem. "Entretanto, essas fases da vida não eram, até a consolidação do modelo capitalista, objeto de saberes. Sobre a velhice não incidia nenhum valor, nenhum discurso, nenhum saber, nenhuma preocupação." (RAMOS, 2014, p. 23).

O presente artigo objetiva, em linhas gerais, estudar a questão da exclusão social do idoso do ambiente urbano - principalmente no que tange à obliteração do seu direito de ir e vir, bem como de participar da vida em comunidade em razão dessa exclusão. Para isso, divide-se o seu desenvolvimento em três capítulos, cada qual correspondendo a um objetivo específico, conforme se segue abaixo.

Seu primeiro capítulo irá desenvolver o marco teórico de observação do problema. Inicia-se com uma passagem da abordagem de Lefebvre acerca do que seria o direito à cidade, à abordagem sistêmica, embasada na inclusão e exclusão das comunicações como questões atinentes aos direitos humanos.

Já o seu segundo capítulo busca apresentar fatores histórico-filosóficos e científicos acerca de quem é o idoso e de como este é considerado excluído da sociedade. Além disso, detalha a teorização acerca da inclusão das comunicações como sendo um direito humano. As comunicações jurídicas, aqui, dizem respeito às relações comunicativas de sentido jurídico (conforme o código "direito/não direito" e ao programa condizente às operações de sentido jurídico, conforme a lógica sistêmico-autopoiética), sendo dado especial enfoque àquelas que dizem respeito ao direito à cidade como um direito humano. Já as comunicações políticas dizem respeito àquelas que se pautam no código "poder/oposição" e no programa produzido pelas operações políticas realizadas pelo próprio sistema comunicativo político - e que podem dizer respeito tanto a uma lógica maior de poder da sociedade (que engloba não apenas a política operada no âmbito estatal até a política no seu sentido mais amplo, englobando também outros atores sociais, tais como movimentos, organizações e etc.) quanto ao poder institucionalizado no Estado, que resulta em políticas públicas (expressas em leis, decretos, etc.).

Por fim, seu terceiro capítulo se centra nas políticas de inclusão do idoso. Foca-se mais acuradamente na exclusão do idoso do ambiente urbano, com dados científicos acerca de 
fatores de exclusão no mundo e no Brasil, exemplificando-se, também, de que forma o prejuízo na mobilidade urbana da terceira idade é um fator incrementador de sua exclusão decorrente do próprio envelhecimento biológico.

O problema que motivou esta pesquisa pode ser descrito interrogativamente, da seguinte maneira: de que forma(s) o idoso se encontra excluído das comunicações políticas relacionadas aos direitos de acessibilidade e mobilidade urbanas? A hipótese que se apresenta é de que a exclusão do idoso, afetado pelo envelhecimento biológico, encontra reflexos, no que tange à cidade, na falta de preocupação para com a mobilidade desse setor populacional vulnerável - o que se expressa na pouca presença do idoso nas comunicações políticas e jurídicas, resultando em políticas públicas quanti e qualitativamente insuficientes para esse grupo populacional.

Justifica-se a importância desse estudo por várias razões - sendo a principal delas, para a sociedade, o aumento do envelhecimento da população em geral no mundo e no Brasil aumento quantitativo este que não encontra correspondência qualitativa (e quantitativa, também) nas políticas públicas desenvolvidas em relação ao idoso. Isso se verifica na frágil adequação das infraestruturas urbanas voltadas à mobilidade e ao bem-estar do idoso (e, consequentemente, em sua vida digna na cidade). Para ilustrar esse aumento, apresentam-se estimativas do Fundo Populacional da Organização das Nações Unidas (2012, p. 3):

Atualmente uma em cada 9 pessoas no mundo tem 60 anos ou mais, e estima-se um crescimento para $1 \mathrm{em}$ cada 5 por volta de 2050. [...] Em 2050 pela primeira vez haverá mais idosos que crianças menores de 15 anos. Em 2012, 810 milhões de pessoas têm 60 anos ou mais, constituindo $11,5 \%$ da população global. Projeta-se que esse número alcance 1 bilhão em menos de dez anos e mais que duplique em 2050, alcançando 2 bilhões de pessoas ou 22\% da população global.

No Brasil essa tendência não é diferente. Segundo dados do IBGE (Instituto Brasileiro de Geografia e Estatística), os idosos - pessoas com mais de 60 anos - somam 23,5 milhões dos brasileiros, mais do que o dobro do registrado em 1991, quando essa mesma faixa etária contabilizava 10,7 milhões de pessoas. Na comparação entre 2009 (última pesquisa divulgada) e 2011, o grupo aumentou 7,6\%, ou seja, mais 1,8 milhão de pessoas. Há dois anos, os idosos eram 21,7 milhões de pessoas (BRASIL, 2018). Ademais, essa população se encontra cada vez mais urbanizada, sendo que tratar da mobilidade urbana do idoso não se trata de simplesmente pensar no acesso de uma minoria à cidade, mas sim, de um grupo que vem aumentando. Essa mobilidade, ademais, vai para muito além do mero movimento de um ponto a outro da cidade: essa movimentação e ocupação da cidade encontra correspondência direta para com direitos 
humanos e fundamentais (ir e vir, viver em comunidade, comunicar-se com os demais, acesso aos mais variados bens da vida, etc.).

Este artigo se vale do método de interpretação sistêmico-construtivista, de acordo com o qual a sociedade não é composta por indivíduos em si, mas sim, pelas comunicações (interações, organizações, etc.) que se dão entre emissores no âmbito de sistemas de sentido. Trata-se de metodologia embasada nos escritos de Niklas Luhmann e Gunther Teubner, principalmente, segundo os quais toda observação depende do sentido que cada observador atribui aos fenômenos - sendo que há sentidos jurídicos, políticos e econômicos (pelo menos) do mesmo fenômeno social. Sua abordagem é qualitativa, valendo-se da técnica bibliográfico-documental - sendo expostos dados e informações oriundos de livros e artigos sociológicos, jurídicos, históricos e filosóficos acerca do idoso.

\section{DIREITO À CIDADE, DIREITOS HUMANOS E EXCLUSÃO}

É teoricamente mais correto referir-se ao urbano do que à cidade, eis que, enquanto esta se trata de um objeto de estudo definido (e definitivo), aquele é compreensível como fenômeno global. A cidade já é objeto de várias ciências que dela se apropriaram (sociologia urbana, economia urbana, etc.), que fragmentam a realidade (LEFEBVRE, 2004, p. 31); porém, a rua, num sentido materialista dialético, seria marcada pela velocidade e pela percepção sensorial orquestradas por um consumismo, reflexo das relações econômico-industriais. Conforme explicação de Nuñez (2014, p. 100, tradução nossa) acerca do tema,

A cidade é entendida como objeto (espacial), mediação entre mediações (entre a ordem próxima e a ordem distante), e como obra (de arte, fabricada por um grupo). O urbano, como conjunto de relações sociais, lugar de encontro, prioridade do valor de uso, inscrição no espaço de um tempo promovido ao nível de bem supremo. Por ele, devem ser analisadas as distintas espaço-temporalidades sociais, desencontradas e coexistentes, porque o método lefebvriano reconhece uma dupla complexidade: horizontal e vertical. ${ }^{3}$

O urbano é composto e significado por uma complexidade de fatores (LEFEBVRE, 2004, p. 51). Esse deslocamento desvia o foco da cidade como local, possibilitando a compreensão até

\footnotetext{
3 Texto original: "La ciudad es entendida como objeto (espacial), mediación entre mediaciones (entre el orden cercano y el orden lejano), y como obra (de arte, fabricada por un grupo). Lo urbano, como conjunto de relaciones sociales, lugar de encuentro, prioridad del valor de uso, inscripción en el espacio de un tiempo promovido al rango de bien supremo. Por ello, deben analizarse las distintas espaciotemporalidades sociales, desencontradas y coexistentes, porque el método lefebvriano reconoce una doble complejidad: horizontal y vertical".
} 
mesmo daquilo que não faz parte da cidade pura e simplesmente, mas que sofre influências (ou, até mesmo, subjugações das mais variadas ordens), como o campo: a relação campo/cidade seria estabelecida pelo urbano, e o rural, influenciado por tal movimentação. Indica o autor, ainda, a necessidade semântica de se definir o urbano como "campo diferencial" (LEFEBVRE, 2004, p. 57), salientando ser a diferença noção essencial para a compreensão teórica da complexidade urbana.

A partir da obra de Lefebvre, Guimarães aponta para possibilidades de integração entre o social, o político e o jurídico - buscando aproximar tais conceitos, num direito à cidade que não seja apenas o direito àquilo que já existe no urbano, mas também o direito de participar da construção do novo (GUIMARÃES, 2017, p. 626-665). Aponta a autora, assim, nessa perspectiva, que essa integração se expressa da seguinte forma na noção de direito à cidade:

O direito à cidade relaciona-se, assim, aos anseios de quem mora, trabalha, sobrevive, produz no espaço urbano: ele deve ser definido por processos de participação - que não sejam meramente formais -, pelas experiências, inclusive as práticas espontâneas vivenciadas na cidade. Ele está marcado pelo poder de alteração e decidir, de modo amplo, os destinos e projetos para o espaço urbano. Trata-se, portanto, de conteúdo que terá diretos reflexos jurídicos, podendo-se destacar o direito à gestão democrática da cidade (GUIMARÃES, 2017, p. 632-633).

Interessante a tentativa de integração entre tais perspectivas, eis que o social não se dá em âmbitos hermeticamente fechados: o social é construído também pelo jurídico e pelo político, e tais formas de comunicar apresentam diversos pontos em comum (ou, como se poderia interpretar sistemicamente, diversos acoplamentos estruturais). Contudo, há que se apontar que, ao simplesmente se tratar dos anseios dos indivíduos que ocupam o espaço urbano, deve-se considerar a complexidade não apenas social da questão, mas também psíquica. Ora, como integrar a perspectiva psíquica de cada indivíduo à complexidade social da questão? A participação democrática é um dos caminhos apontáveis segundo a autora. Porém, trata-se de apenas uma possibilidade, e não a única.

Ademais, em que pese a importância da teorização de Lefebvre, sendo o autor materialista-dialético (de inspiração diretamente marxista, portanto), pode-se analisar em sua obra um caráter economicista. Expressões como mais-valia, divisão do trabalho, revolução e luta de classes são importantes para uma compreensão econômica do fenômeno urbano (e da sua irritação no sistema político), mas são instrumentos que não são capazes de descrever de modo mais amplo o fenômeno urbano segundo o autor. Faz-se necessário, portanto, abarcar os conceitos de complexidade e diferença presentes em sua obra, e esmiuçá-las a partir de outros pontos de vista, para além do econômico. 
Mas o elemento complexidade do urbano ainda resta como importantíssimo em sua teorização. Entender o urbano na multiplicidade de possibilidades de sentido no que há de urbano. As múltiplas possibilidades de reflexividade entre político e jurídico; econômico e político; jurídico e econômico (sem esquecer outras possibilidades, tais como científicas, artísticas, espaciais e etc.) fornecem à observação do urbano lentes que vão para além da análise do espaço pura e simplesmente. Ou seja: o urbano não pode ser observado em apenas uma (mono) contextualização, textualização ou textura lógica: são necessárias várias dimensões lógicas para a observação do urbano.

Uma lógica afeita à aristotélica seria monocontextural, eis que apenas o "ser" e o "não ser" seriam possíveis: ou algo é conforme determinada lógica, ou não o é, de forma que uma terceira opção não seria possível (GÜNTHER, 2004, p. 3-4; FORNASIER, 2015b, p. 45). Algo é "urbano" ou algo é "rural", num sentido espacial (ou "cultural"), por exemplo. Essa racionalidade se revelou importante para a história do pensamento humano, mas se torna insuficiente quando se está diante de um cenário hipercomplexo. Várias lógicas, de vários códigos binários (lógicos, não normativos) diferenciados, seriam possíveis em tal ordem de coisas, formando-se, desta forma, várias contexturalidades, cada qual com seu respectivo par ordenado "conforme/em desconformidade" - mas que observam uns aos outros, fazendo-se, assim, ligados de certa forma: obtém-se, assim, uma estrutura multinivelada de lógicas de extrema complexidade. "Uma contexturalidade é um domínio lógico de uma estrutura estritamente valorada em dois valores, e sua abrangência é determinada pelo uso do TND [Lógica "Tertium Non Datur", sem terceiro elemento possível]". [...] quando se considera, todavia, que o Universo deve ser considerado como uma "intersecção de um número ilimitado de contexturalidades duplamente valoradas" (GÜNTHER, 2004, p. 6; FORNASIER, 2015b, p. 45), está-se diante de uma pluralidade de contexturalidades - ou seja, uma situação de policontexturalidade.

A lógica policontextural é adotada por Luhmann quando da sua definição de sociedade moderna. "[...] A sociedade moderna [...] é um sistema policontextural que permite um número infindável de descrições sobre sua complexidade" (LUHMANN, 2007, p. 21-22, tradução nossa), ${ }^{4}$ não se podendo esperar, da teoria da sociedade que analisa o urbano, uma descrição monocontextural. Diante deste cenário teórico, tem-se que haverá várias possibilidades de auto-observações: um sistema (e.g. a economia, ou o direito) apenas observa a si próprio,

\footnotetext{
${ }^{4}$ Texto original: "[...] la sociedad moderna [...] es un sistema policontextural que permite un sin numero de descripciones acerca de su complejidad".
} 
sendo que, quando o faz em relação a outro sistema, na verdade, observará aquilo que, em si próprio, há de observado acerca do outro. Um sistema, assim, observa a si mesmo e ao outro, simultaneamente (LUHMANN, 2007, p. 62 a 64).

Se a modernidade se inicia sob a égide da realização do progresso mediante a sociedade, as teorias malthusianas, já ao final do século XVIII, demonstravam que era irrealizável este projeto. A partir do século XIX, passou-se a tratar das questões da solidariedade social (LUHMANN, 1997, p. 69), concebida como uma espécie de obrigação moral, ou como uma consciência coletiva - mas logo se percebeu que esta moralidade/consciência não passava de uma cristalização contingente temporária (LUHMANN, 1997, p. 68). É justamente este o período em que a industrialização começa a fazer emergir o fenômeno da urbanização para além do mero estabelecimento espacial da cidade (LEFEBVRE, 1976, p. 63-64).

Mas a complexidade ligada ao urbano não se dá apenas em nível (não hierárquico) sistêmico-social, mas também, no que se refere ao sistema psíquico de cada indivíduo - ou seja, no que tange às percepções individuais, sensoriais. Andreas Philippopoulos-Mihalopoulos (2007, p. 54, tradução nossa) expressa a necessidade de se inserir, na análise sociojurídica da cidade, esse fator:

A cidade é uma reiteração fractal da fronteira entre percepção e comunicação, autodescrição e descrições, apreensão e representação sensorial, corporeidade e coexistência espacial, monadologia e nomadologia, sistema e seu observador: em suma, uma forma que se repete implacavelmente sem nunca perder de vista o paradoxo original. ${ }^{5}$

Em outras palavras, cada observador ("ente", "indivíduo", "pessoa", sistema psíquico individual) irá (re)criar a realidade do urbano a partir do seu programa pessoal (sentimentos, percepções) após observá-lo. Assim, o bem estar, a felicidade (ou, ao menos, um mínimo satisfatório) depende não do estabelecimento de uma "felicidade padrão" por cada sistema (pelo Direito, pela Política, etc.) - pois assim como cada sistema psíquico tem suas percepções próprias acerca dessa satisfação de necessidades, cada sistema social também embasará sua decisão acerca desse mínimo de inclusão a partir de seu próprio programa.

O século XX não trouxe nem felicidade, nem solidariedade; aliás, esta segunda se tornou um eufemismo para várias utilizações (LUHMANN, 1997, p. 69). A partir de então, a sociedade

\footnotetext{
${ }^{5}$ Texto original: "The city is a fractal reiteration of the boundary between perception and communication, self-description and descriptions, sensory apprehension and representation, corporeality and spatial coexistence, monadology and nomadology, system and its observer: in short, a form that relentlessly repeats itself without ever losing sight of its original paradox. Through a catenation of autopoietic events, the city continues its mutual undercutting with its environment while reserving a place for undomesticated ignorance".
} 
passa a se pretender "ativa", em busca de similaridade de condições de vida em todo o mundo - e esta aspiração é reproduzida pela mídia de massa e pelo mercado globalizados, mas nunca sai do nível da mera aspiração, não tendo sido realizada: as promessas da sociedade não se concretizam, degenerando-se em discrepâncias crescentes em frequência e obviedade.

O ocaso do século XX fez com que uma lição fosse aprendida: ter de viver em uma sociedade sem felicidade, bom gosto, solidariedade ou similaridade de condições de vida. Insistir em tais aspirações pode apenas levar a novas utopias, as quais se demonstrarão igualmente decepcionantes na estreita envergadura das possibilidades políticas. São fantasmas garantidores de uma unidade do sistema. Mas é impossível introduzir a unidade do sistema no sistema: os maiores problemas da sociedade não são mais as injustiças decorrentes da estratificação - que poderiam ser resolvidas pelo apelo à razão (crítica, reforma das instituições, revolução, etc.) (LUHMANN, 1997, p. 69).

Nesse cenário complexo, de relativização (mas não de destruição ou erosão, como muitos críticos poderiam apontar) de fronteiras nacionais, de enormes fluxos (de informação, de pessoas, de recursos econômico-financeiros) circulando em escala global, massas de excluídos surgem e se intensificam (migrantes, desempregados, escravizados, pessoas sem acesso a um mínimo existencial decente - não importando a origem desse padrão de "decência") se evidenciam, e uma noção de "progresso" (evolução teleologicamente guiada), simplória e linear, não se evidencia como suficiente (seja na práxis, seja na teoria) para a compreensão do mundo policontextural, hipercomplexo e globalizado no tocante ao humano. É nesse cenário que Ralf Rogowski (2015, p. 8) relembra o alerta já dado por Luhmann, de uma distopia similar àquela do Homo Sacer, apontada por Giorgio Agamben (2002).

O pior cenário imaginável pode ser que a sociedade do próximo século terá que aceitar o meio de inclusão/exclusão. E isso significaria que alguns seres humanos serão pessoas e outras, indivíduos, apenas; que alguns são incluídos em sistemas de função para carreiras (bemsucedidas ou mal sucedidas) e outros são excluídos desses sistemas, corpos remanescentes que tentam sobreviver no dia seguinte; que alguns são emancipados como pessoas e outros são emancipados como corpos. Essa preocupação e negligência tornam-se diferenciadas ao longo desta fronteira; que o estreito acoplamento de exclusões e acoplamentos frouxos de inclusões diferenciam destino e sorte: e que duas formas de integração competirão: a integração negativa de exclusões e a integração positiva de inclusões (LUHMANN, 1997, p. 76, tradução nossa). ${ }^{6}$

\footnotetext{
${ }^{6}$ Texto original: "The worst imaginable scenario might be that the society of the next century will have to accept the metacode of inclusion/exclusion. And this would mean that some human beings will be persons and others only individuals; that some are included into function systems for (successful or unsuccessful) careers and others are excluded from these systems, remaining bodies that try to survive
} 
Com a observação das enormes massas privadas do essencial para a vida humana decente em razão da impossibilidade de acesso a qualquer sistema funcional (possibilidade de aprender no sistema da educação; de demandar, no sistema jurídico; de interagir no mercado, na economia; de participar dos procedimentos decisórios na política), os termos "exploração" e "supressão", muito adequados para sociedades estratificadas, se demonstram insuficientes para explicar problemas da sociedade funcionalmente diferenciada. São utopias negativas e datadas, que conduzem soluções mitológicas igualmente ultrapassadas (geralmente "revolucionárias"). É nessas massas que se encontra, também, o idoso como excluído.

A sociedade funcionalmente diferenciada exige o raciocínio do tipo inclusão/exclusão. Sociedades tradicionais realizavam a inclusão (ou exclusão) mediante a lógica do seio familiar, e as famílias eram distribuídas em estratos. A sociedade moderna, por seu turno, exclui as pessoas de forma muito mais paradoxal: os sistemas funcionais pressupõem a inclusão de todos os seres humanos, mas de fato, excluem pessoas que não preenchem seus requisitos (registros públicos, educação institucionalizada, trabalho regular, capacidade para acessar a justiça, etc.), e um tipo de exclusão serve de fundamento para os demais. A sociedade funcionalmente diferenciada, no tocante ao raciocínio excludente é, portanto, firmemente integrada - e valores modernos (igualdade, liberdade, autorrealização individual) apenas significam o encobrimento da preservação de uma ilusão de inocência. Cabe aqui um adendo: o primado da diferenciação funcional não oblitera a existência de classes socioeconômicas - muito pelo contrário: a exclusão operada nesta lógica as produz, mas como subproduto.

Não há uma unidade teórico-social adequada para conter todos os sistemas representativos do humano (biológico, psíquico e comunicativo); porém, isso não significa a inexistência de um "humano" para a teoria dos sistemas autopoiéticos: tal raciocínio apenas afasta a possibilidade de configuração absoluta de um antropocentrismo em nível de teoria sociológica (FORNASIER; LEITE, 2016, p. 915; LUHMANN, 1996a, p. 226). Tem-se, com isto, que o essencial não é definir o que é o ser humano para os Direitos Humanos, mas sim, em conceber o sentido do humano na comunicação específica estabelecido pelos sistemas do Direito e da Política (sendo que, aqui, se tratará em específico de políticas públicas concernentes à acessibilidade e à mobilidade do idoso no ambiente urbano).

the next day; that some are emancipated as persons and others are emancipated as bodies; that concern and neglect become differentiated along this boundary; that tight coupling of exclusions and loose couplings of inclusions differentiate fate and fortune: and that two forms of integration will compete: the negative integration of exclusions and the positive integration of inclusions". 
A expressão "Direitos Humanos" tem, geralmente, seu sentido ligado a noções surgidas no contexto das revoluções liberais, e que se combinava ao conceito de cidadania. Diferenciavase da noção de "direitos do homem", pois esta última era ligada aos direitos de todos aqueles que detivessem a condição humana, independentemente da pertença a uma comunidade política (NEVES, 2009, p. 249-250). O desenvolvimento da ideia de Direitos Humanos, assim, é desenvolvida também com as dimensões política (participar da escolha acerca do governo, em geral) e social (direitos, em stricto sensu, prestacionais a serem atendidos pelo Estado) - para além da ideia original, de liberdades negativas em relação ao Estado.

Foi com o constitucionalismo alemão das primeiras décadas do século XX (com a Constituição de Weimar, especificamente) que a expressão "direitos fundamentais" passou a ser usada em referência a direitos positivados e garantidos em Constituições estatais - sendo incluídos nesta categoria, porém, tanto os direitos liberais de cidadania quanto os Direitos Humanos (SCHMITT, 1992, p. 164 e ss.). Com isso, passa a ser estabelecida, teoricamente, a distinção entre Direitos Humanos internacionalmente protegidos (afirmáveis, inclusive, contra os Estados) e os direitos fundamentais garantidos constitucionalmente pelos Estados (DIMOULIS; MARTINS, 2007, p. 40 e ss.). Mas seus conteúdos se entrecruzam nas categorias de direitos civis, políticos, sociais e novos direitos (transindividuais, principalmente) (FORNASIER; LEITE, 2016, p. 916; NEVES, 2009, p. 250).

Uma abordagem sistêmica dos direitos também deve considerar as distinções entre as categorias fundamentais e humanos. Os primeiros (constitucionalmente positivados), assim, teriam a função de manter uma ordem diferenciada de comunicação (reagindo, assim, ao "perigo da desdiferenciação") (LUHMANN, 2010, p. 98-99). Apesar de, em suas primeiras obras, ter desprezado a noção de direitos humanos por considerá-los "eternos", Luhmann (2010, p. 99) posteriormente enfatizou que "entre os mais importantes indicadores de um Sistema jurídico global está a crescente atenção dada à violação de direitos humanos" (FORNASIER; LEITE, 2016, p. 915; LUHMANN, 2004, p. 482).

Os Direitos Humanos guardam relação direta, sistemicamente, com o problema da exclusão - sendo que sua orientação se dá no sentido da inclusão do ser humano como pessoa nos sistemas sociais funcionais (especialmente no Direito) (FORNASIER; LEITE, 2016, p. 915; LUHMANN, 2004, p. 490). Nesta senda, quando alguém não é comunicado sobre si em um sistema já se está violando seus Direitos Humanos - cuja função é, especificamente, criar condições, no programa de um sistema, para que determinadas pessoas, categorias e grupos 
tenham reconhecida a sua condição/situação e, com isso, que venham a ser titulares de direitos que os equalizem em condições para com os demais.

Reforça esse argumento Marcelo Neves (2009, p. 252) que entende que, para além das violações extremas aos direitos humanos avalizadas (de uma forma ou outra) pelo Estado, também deve ser entendida como violação:

[...] a falta de condições mínimas de sobrevivência para grande parte da população na sociedade mundial de hoje, implicando como que uma exclusão social absoluta dos respectivos grupos humanos [...]. Trata-se do paradoxo da afirmação de expectativas normativas (contrafactuais) diante da própria prática que as contraria sistematicamente. A diferença reside no fato de que aqueles direitos humanos em sentido estrito, que se referem basicamente à proibição de ações violentas [...] contra indivíduos ou grupos, são suscetíveis de institucionalização e, sobretudo, contam com perspectivas de positivação e implementação processual em escala mundial, [...] enquanto os chamados direitos humanos de terceira geração são fragilmente institucionalizados, e as perspectivas de sua positivação e implementação processual em extensão mundial são negativas.

Com essa proposta, os Direitos Humanos são redefinidos como sendo expectativas normativas destinadas à inclusão de todos os seres humanos na sociedade mundial delineando-se como o acesso universal ao subsistema social do Direito (NEVES, 2005, p. 8-10). Este raciocínio acerca de tais direitos não se chocaria com a mais atual das concepções luhmannianas recém apresentadas, pois continua a ser sustentado que os Direitos Humanos reagem ao perigo da desdiferenciação - já que a manutenção de uma ordem diferenciada de comunicação na sociedade mundial e a orientação pela inclusão das pessoas nos sistemas funcionais (inclusive no Direito) são ideias intimamente ligadas (NEVES, 2009, p. 253). Em outras palavras, quanto menor for a exclusão de pessoas dos sistemas sociais, mais realizada estará a diferenciação funcional dos sistemas parciais da sociedade (Direito, Política, Economia, etc.) (LUHMANN, 2004, p. 488; FORNASIER; LEITE, 2016, p. 917).

A passagem da diferenciação estratificada (resumidamente, dividida em estamentos) à funcional (dividida em sistemas), que se deu com a Modernidade, é acompanhada da complexificação social - a qual, por sua vez, é terreno fértil para a evolução social: e isso é notável na própria semântica das comunicações. Evolução vem a significar um processo não linear e não teleológico, em que variação, seleção e estabilização se sucedem (LUHMANN, 2004, p. 232) - e, no que toca aos direitos humanos como inclusão, há uma relação direta entre a seleção e a aceitação social de outras formas de vida:

[Com a] transição de uma diferenciação estratificada para uma diferenciação funcional do sistema, a evolução global da sociedade obriga 
a uma inclusão mais forte, possivelmente mais abrangente de todos os círculos da população em todos os campos funcionais. Também aqui a evolução tem igualmente algo a ver com exigências contraditórias, às quais se admite um cunho semântico: por um lado, tem de se tornar viável o que é especial, o que é inverossímil, por outro, é exatamente isto que tem de ser alcançável para toda a gente. Por um lado, a sociedade necessita da estratificação para a introdução da inverossimilhança e para a reorganização com vista à diferenciação plena dos sistemas de função, por outro, é precisamente tal reorganização que arruína a necessidade e a possibilidade de estratificação. Superar essas contradições, acentuar as exigências diversas, expô-las em controvérsia, relacioná-las umas com as outras, transmiti-las, parece ser a missão da semântica (LUHMANN, 1991, p. 53).

Direitos Humanos e fundamentais, em que pese pertençam a âmbitos diversos (aqueles, global; estes, nacional), são respectivos à busca pela inclusão da pessoa. A diferença entre as nomenclaturas (humanos ou fundamentais) residiria, assim, apenas no seu âmbito de pretensão de validade: enquanto os Direitos Humanos pretendem validade para o sistema jurídico mundial de múltiplos níveis, os fundamentais encontram validade no interior de uma ordem constitucional determinada de um Estado (FORNASIER; LEITE, 2016, p. 915; NEVES, 2009, p. 253-254).

Gunther Teubner (2006, p. 338) propõe uma distinção entre direitos humanos e fundamentais a partir do conteúdo de cada um: estes se orientariam à inclusão da pessoa, enquanto aqueles, à exclusão do homem da sociedade, a fim de garantir-lhes integridade biológica e psíquica em relação à sociedade- afirmando que os direitos humanos "devem ser entendidos como possuindo uma diferença semântica das liberdades comunicativas pessoais, nomeadamente como garantias intentadas da integridade de corpo e mente"-e, nesse mesmo sentido, "a questão dos direitos humanos no sentido mais estrito deve hoje ser vista como a periclitação da integridade de mente e corpo dos indivíduos por uma multiplicidade de processos comunicativos anônimos e, atualmente, globalizados" (FORNASIER; LEITE, 2016, p. 915; TEUBNER, 2006, p. 341).

Há uma grande e complexa gama de indivíduos excluídos no cenário global: imigrantes, miseráveis, desempregados, pessoas com deficiência, perseguidos religiosos e políticos, etc. Há meios de exclusão por ação (ou seja, literalmente, perseguir e barrar; destruir e etiquetar como excluído), mas também, por omissão (simplesmente não comunicar o direito e a existência de tais indivíduos já é uma terrível forma de exclusão). Porém, há que se identificar, também, uma série de excluídos que o são por questões sociais apenas (incapacidade de consumir, nacionalidade, comportamento considerado incorreto) - mas outros possuem características 
biológicas que são consideradas socialmente pejorativas (sexo, idade, genética, incapacidades físicas e psíquicas). Dentre os segundos encontram-se os idosos, sobre os quais muito já se comunicou - e se comunica - em diversos sistemas sociais, ao longo da história.

\section{O IDOSO COMO EXCLUÍDO DA SOCIEDADE}

Na civilização oriental, especialmente na China, desde a Antiguidade até os dias atuais, o idoso sempre mereceu uma posição privilegiada. A partir de Silvana Sidney Costa Santos (2001), pode-se remontar desde o filósofo Confúcio (551-479 a.C.) o pensamento acerca da velhice: para o referido pensador, a base epistemológica era a família - assim, acreditava que a autoridade da velhice é justificada pela aquisição da sabedoria. Os filhos mais jovens devem obediência, respeito e amor para com seus pais. Para Confúcio (1999), não há nada no mundo tão grande como o ser humano; e, no ser humano, nada é maior que a piedade filial.

Já a civilização ocidental considera a questão do envelhecimento de modo diverso, conforme Santos (2001, p. 92). No ano 2.500 a.C,, a imagem obsessiva do corpo humano belo e perfeito tornou-se evidente desde os tempos mais antigos. Simone de Beauvoir (1990, p. 14) descreve um trecho da primeira obra que se referiu à velhice, que foi elaborada no Egito por Ptah-Hotep, filósofo e poeta que nos mostra a face cruel do processo de envelhecimento, ao afirmar que:

Quão penoso é o fim do ancião! Vai dia a dia enfraquecendo: a visão baixa, seus ouvidos se tornam surdos, o nariz se obstrui e nada mais pode cheirar, a boca se torna silenciosa e já não fala. Suas faculdades intelectuais se reduzem e torna-se impossível recordar o que foi ontem. Doem-Ihe todos os ossos. A ocupação a que outrora se entregara com prazer, só a realiza agora com dificuldade e desaparece o sentido do gosto. A velhice é a pior desgraça que pode acontecer a um homem.

Na Idade Antiga, época em que os poderosos que despontavam (reis, faraós, etc.) tinham como objetivo principal a conquista territorial, homens fisicamente perfeitos eram necessários para fazer parte de seus exércitos (SANTOS, 2001, p. 92). Em Atenas era recomendado que homens exortassem seus corpos nus, e o ato de exibir-se simbolizava com frequência um povo autoconfiante e totalmente à vontade. Tanto que para Péricles, a "cidade [em grego - polis] significava o espaço onde as pessoas alcançavam a mais alta expressão da unidade" (SENNET, 2008, pp. 44-45; LEITE, 2015, p. 150).

Em Roma, a imagem obsessiva do corpo ideal também teve seu lugar e tempo na exclusão dos idosos na sociedade, bem como na construção do espaço urbano. "O imperador 
precisava que seu poder fosse evidenciado em monumentos e obras públicas. O governo não existia sem a pedra" (SENNETT, 2008, p. 93). Assim, a influência do corpo humano belo e perfeito tornou-se evidente na forma urbana dessa época, sendo a velhice, tratada e vista, de modo geral, com desprezo e com certa crueldade (LEITE, 2015, p. 151).

Ao escrever A República, Platão (1985) mostra passagens onde Sócrates faz referências ao envelhecimento, como a ideia de que para os seres humanos prudentes e bem preparados, a velhice não constitui peso algum. Para tanto, Simone de Beauvoir (1990, p. 135) transcreve um diálogo travado entre Sócrates e Céfalo sobre a velhice:

Céfalo convidou Sócrates para visitá-lo, desculpando-se por não ir procurá-lo, pelo fato de estar velho e ser difícil sair de casa. Queria conversar com o amigo, pois para Céfalo, quanto mais amortecidos ficam os prazeres do corpo, mais crescem o deleite e o prazer da conversação. Sócrates aceitou o convite, respondendo que lhe agrada muito conversar com pessoas de mais idade, que já tinham percorrido um caminho que ele teria que percorrer. Assim, deu-se o início da conversa, quando Sócrates perguntou a Céfalo, como ele, já velho, sentia-se ao atingir a fase que os poetas chamavam de o limiar da velhice. Céfalo respondeu que muito bem, pois a triste cantilena, evocada por muitos, responsabilizando a velhice por todos os males, para ele era decorrente da própria vida e não da idade avançada.

Em relação ao envelhecimento, Aristóteles achava que uma boa velhice seria aquela em que o indivíduo não apresentasse enfermidades (SANTOS, 2001, p. 93). Na Ética, onde se concentra seus escritos mais famosos, ensina que o ser humano progride somente até os 50 anos. Essa concepção distorcida de velhice fazia-o ver os idosos como pessoas diminuídas, indignas de confiança e por isso precisavam ser afastadas do poder, não devendo exercer cargos de importância política (CRESCENZO, 1988).

Conforme Santos (2001, p. 94), no primeiro século antes da Era Cristã, Marco Túlio Cícero (103-43 a.C.), o grande filósofo romano, político, jurista e orador, demonstrou-se uma figura exponencial nos estudos sobre a velhice. Para esse filósofo, a arte de envelhecer está em descobrir o prazer que todas as idades proporcionam, pois todas têm as suas virtudes (CíCERO, 2001).

Tratar teoricamente do envelhecimento, portanto, é algo que, assim como o início e o fim da vida, representa uma das maiores angústias da humanidade. Afinal, pela lógica natural da existência, os homens nascem, crescem, amadurecem e morrem.

Entretanto, essas fases da vida não eram, até a consolidação do modelo capitalista, objeto de saberes. Sobre a velhice não incidia nenhum valor, nenhum discurso, nenhum saber, nenhuma preocupação. Não era tema de relevância. (RAMOS, 2014, p. 23) 
Conforme indicam Braga, Leite e Bahia (2017, p. 432-436), a partir do século XIX, na medida em que o processo de industrialização avança, há a exigência de mão de obra mais qualificada, a qual requeria tempo e gastos para sua preparação. Dentro desse contexto, passa a ser conveniente que os trabalhadores também vivessem (produtivamente) mais para recompensar os recursos gastos com a sua capacitação. Aliado a esse fator, em virtude do aumento da expectativa de vida, reflexo do desenvolvimento e progresso das sociedades, o idoso passa a usufruir de melhores condições psicológicas e físicas. Assim, como resultado dessa sociedade cada vez mais complexa, que exigia uma nova postura diante da existência, especialmente de sua duração como condição essencial para a própria sobrevivência do sistema em fase de afirmação, "a velhice passou a se apresentar como fenômeno não somente biológico, mas fundamentalmente social" (RAMOS, 2014, p. 23).

Nota-se, portanto, na filosofia ocidental, uma tensão entre o idoso-excluído e o idosoventuroso; contudo, na era industrial, passa-se a reforçar, de um lado, o sentido da exclusão, eis que o envelhecido não corresponde, nas suas capacidades, às necessidades velozes e bem calculadas da economia; de outro, o avançar da idade e da expectativa de vida, proporcionadas (e perseguidas) pelo desenvolvimento científico e econômico industrial passa a demandar um envelhecimento com maior qualidade.

A questão do envelhecimento não se tornou socialmente relevante apenas pela quantidade cada vez maior de idosos em nossas sociedades, mas, especialmente, pelo motivo dessas pessoas e demais grupos vulneráveis, tais como pessoas com deficiência, crianças e adolescentes, dentre outros, e demais grupos sociais a eles solidários, terem se mobilizado no sentido de exigir que direitos essenciais Ihes fossem reconhecidos. A preocupação em assegurar os direitos das pessoas idosas, no âmbito internacional e internamente, deu-se recentemente. Cabe esclarecer que, diferentemente do que ocorre em relação a outros grupos vulneráveis, como o das pessoas com deficiência, o grupo de idosos não possui ainda um instrumento jurídico internacional, de caráter vinculante, para a defesa dos seus direitos fundamentais.

No Brasil, a Constituição Federal de 1988 inaugura uma nova fisionomia do Estado brasileiro, vez que não somente oconsagrou democrático, mas também ressaltou o seu caráter essencialmente social, ao fundá-loem valores como a dignidade humana e cidadania, que irradiarão seus efeitos sobre todo o ordenamento. Esse novo modelo de Estado tem a tarefa fundamental de superar as desigualdades, não apenas econômicas e sociais, mas também as desigualdades ocasionadas em razão de raça, cor, sexo, condições físicas e de idade. Ao 
destacar essas desigualdades, a Constituição inseriu a proteção constitucional às pessoas idosas. Assegurou-a de forma direta à velhice em seus artigos 229 e 230.

No plano infraconstitucional, foi promulgada a Lei no 8.842/1994 que dispõe sobre a Política Nacional do Idoso, com objetivo de assegurar os direitos sociais ao idoso, criando condições para promover sua autonomia, participação efetiva e integração na sociedade. $\mathrm{Na}$ sequência, é instituído o Decreto no 4.227/2002, que cria o Conselho Nacional dos Direitos dos Idosos, órgão vinculado ao Ministério da Justiça, com competência para supervisionar e avaliar a Política Nacional do Idoso, entre outras funções relacionadas à matéria. E, após 10 anos da edição da lei sobre a política nacional do idoso, em janeiro de 2004, entra em vigor a Lei no 10.741/2003, denominada Estatuto do Idoso, estabelecendo regras de direitos para proteção às pessoas com idade igual ou superior a 60 (sessenta) anos.

Trata-se de uma legislação atualizada, na mesma linha do Estatuto da Criança e do Adolescente e do Código do Consumidor. É um verdadeiro microssistema jurídico, regulamentando todas as questões que envolvem a pessoa idosa, tanto no aspecto material quanto processual. O Estatuto do Idoso está estruturado em sete Títulos, a saber: Título I - Das Disposições Preliminares; Título II - Dos Direitos Fundamentais, este composto de dez Capítulos; Título III - Das Medidas de Proteção, subdividido em dois Capítulos; Título IV - Da política de atendimento ao idoso, com seis Capítulos; Título $V$ - Do acesso à Justiça, disciplinado em três Capítulos; Título VI - Dos Crimes, com dois Capítulos; e Título VII - Das Disposições Finais e transitórias, enfeixando 118 artigos.

Cabe esclarecer que o Estatuto do Idoso incorporou e reafirmou, em seu texto, a doutrina da proteção integral, antes já utilizada no Estatuto da Criança e do Adolescente. Encontraremos ao longo do texto legal dispositivos que vêm para suprimir as deficiências sofridas pelos idosos no âmbito político e social.

Enfim, a Lei 10.743/03 vem para consolidar a matéria jurídica relativa aos direitos e garantias do cidadão idoso. Afinal, o Brasil não é mais um país de jovens, mas um país em acelerado processo de envelhecimento. Esse perfil populacional exigirá do Estado e de toda sociedade ações efetivas para garantia dos direitos fundamentais das pessoas envelhecidas (BRAGA; LEITE; BAHIA, 2017, p. 434).

O envelhecimento deveria ter sido considerado pelo legislador como um processo tipicamente individual, existencial e subjetivo, afinal, cada existência humana é única, cada ser humano envelhece de maneira particular. Haveria necessidade de levar em consideração que 
cada indivíduo tem um tempo próprio para se sentir velho. Não há velhice e sim velhices. (BRAGA, 2011, p. 3)

Portanto, para desenvolver um conceito preciso sobre a velhice seria necessário considerar inúmeros fatores, uma vez que a velhice é um fenômeno complexo. A condição econômica dessas pessoas, seu grau de instrução, qual o tipo de alimento ingerido por elas, e como são suas relações familiares, dentre outros fatores. Nesse sentido, Paulo Roberto Barbosa Ramos, com base nas lições de Norberto Bobbio (1992), Leonard Hayflick (1998) e Elida Séguin (2001), afirma que para melhor compreensão do conceito de velhice, é necessário compreendê-la na perspectiva cronológica ou censitária, burocrática, fisiológica e psicológica ou subjetiva. A cronológica é aquela meramente formal, numérica, que parte de um patamar que, em sendo alcançado, identifica a quem o alcançou como velho. A velhice burocrática corresponde àquela idade que, ao ser alcançada, preenche condições jurídicas para a pessoa ter direito a uma aposentadoria (ou, ainda, que the garante o direito à tramitação preferencial processual, por exemplo). A fisiológica pode ser identificada como a fragilização da pessoa em virtude do passar dos anos; aquela que diz respeito ao enfraquecimento do organismo. Já a subjetiva é a mais complexa, já que não dispõe de parâmetros. Depende de cada pessoa. Acrescenta também, a velhice excluída (aquela personificada por pessoas envelhecidas que sobrevivem nos meios rurais, suburbanos ou após as migrações), a pseudo velhice (por pessoas de 40 anos ou menos, desempregadas) e a precoce (pessoas que, em razão de condições altamente adversas de existência, envelhecem muito cedo). (RAMOS, 2014, pp. 34-35)

Todavia, o conceito eleito pelo legislador, no artigo 10 do Estatuto do Idoso, ${ }^{7}$ foi o critério cronológico para definir quem é considerado idoso para os efeitos da presente lei. Sendo o idoso a pessoa como idade igual ou superior a 60 anos de idade, homem ou mulher, nacional ou estrangeiro, urbano ou rural, trabalhador da iniciativa privada ou do serviço público, livre ou recluso, exercendo atividades ou aposentado, incluindo o pensionista e qualquer que seja a sua condição social. (MARTINEZ, 2005, p. 20). Porém, na prática, a maioria dos benefícios tem início aos 65 anos. Essa indefinição traz uma série de prejuízos em áreas importantes, cabe destacar o direito à gratuidade no transporte coletivo, que exige a idade mínima de 65 (sessenta e cinco) anos, segundo dispõe o artigo 230, § 2ㅇ da CF/88 e artigo 39, caput do Estatuto. Esta é também a idade exigida para obter prioridade na tramitação de processos judiciais, de acordo com a Lei 10.173, de 09 de janeiro de 2001. E também o do benefício da

\footnotetext{
${ }^{7}$ Art. 1o É instituído o Estatuto do Idoso, destinado a regular os direitos assegurados às pessoas com idade
} igual ou superior a 60 (sessenta) anos. 
prestação continuada nos termos do artigo 34, caput da Lei de Organização da Assistência Social - LOAS.

De qualquer modo, não se pode deixar de destacar que o Estatuto reconheceu o acesso das pessoas com 60 (sessenta) anos ou mais ao pleno gozo de seus direitos, bem como a uma efetiva inclusão nos diversos segmentos da comunidade e o bem-estar delas, garantindo o respeito e a preservação de sua dignidade.

O Estatuto assegurou aos idosos, em seu artigo 2 o, todos os direitos fundamentais inerentes à pessoa humana, sem prejuízo da proteção integral, assegurando por lei ou por outros meios, todas as oportunidades e facilidades, para preservação de sua saúde física e mental e seu aperfeiçoamento moral, intelectual, espiritual e social em condições de liberdade e dignidade.

O Brasil não ficou alheio no que se refere ao sistema internacional de proteção aos direitos humanos. Com o advento da Constituição Federal de 1988, importantes tratados internacionais, voltados a valorização dos direitos humanos foram ratificados pelo Governo Brasileiro. Dentro desse contexto, introduz a Carta Política de 1988 uma evolução significativa no que tange ao estabelecimento textual de direitos e garantias fundamentais. De forma inédita, os direitos e garantias são elevados a cláusulas pétreas, e passam a compor o núcleo material intangível da Constituição (art. 60, § 4ํ). Cria-se uma nova ordem constitucional, em que a dignidade da pessoa humana e os direitos fundamentais tornam-se o ponto central dessa ordem jurídica. Tanto que, em seu preâmbulo, anunciou-se o propósito de construir um Estado Democrático pautado em uma sociedade fraterna, pluralista e sem preconceitos, onde esteja assegurada a igualdade, dentre os fundamentos que alicerçam o Estado Democrático de Direito. Elevou em seu artigo 1으. III, o valor da dignidade da pessoa humana como princípio fundamental desse novo Estado. Consagrou como objetivos fundamentais construir uma sociedade livre, justa e solidária, erradicar a pobreza e a marginalização e reduzir as desigualdades sociais e promover o bem de todos, sem preconceitos, de origem, raça, sexo, idade e quaisquer outras formas de discriminação (artigo 3o e incisos).

E, em seu Título II, a Constituição Federal definiu os "Direitos e Garantias Fundamentais", os quais abrangem os seguintes direitos: direitos individuais e coletivos; direitos sociais; direitos da nacionalidade; direitos políticos; direitos relacionados à existência, organização e participação em partidos políticos. O elenco de tais direitos deu-se através do caput e $\S 1$ 으 do seu artigo 5으, que assegurou o princípio da igualdade, que passa a ser considerado dentro desse novo enfoque introduzido pela Lei Maior, como o valor mais alto dos 
direito fundamentais, funcionando como regra mestra de toda a hermenêutica constitucional e infraconstitucional. Assim, ao garantir a igualdade formal, o artigo 5o cuidou, desde logo, de impedir que determinadas situações fossem prestigiadas sem qualquer correlação lógica. Portanto, o que verificamos é que a Constituição aproximou a igualdade formal da igualdade material, na medida em que não se limitou ao simples enunciado da igualdade perante a lei. "O princípio não pode ser entendido no sentido individualista, que não leve em conta as diferenças entre grupos." (LEITE, 2012, p. 225) Tal proteção é justificada, afinal, torna-se necessária a recomposição de natural desigualdade, quer decorrente de um longo processo de exclusão, quer decorrente raça, sexo, religião, e idade, no caso dos idosos.

Além dessas normas voltadas a uma proteção genérica a todas as pessoas, inclusive aos idosos, a Constituição Federal reconhecendo a necessidade de uma descrição específica do idoso enquanto categoria diferenciada avançou e, a exemplo do que realizou em relação à criança e ao adolescente, aos índios, ao meio ambiente, assegurou, nos artigos 203, 229 e 230 uma proteção especial à velhice. Tais normas de cunho protetivo irão balizar a atuação do legislador infraconstitucional, e as diretrizes da atuação do Estado enquanto implementador de políticas públicas. Vejamos: a assistência social será prestada a quem dela necessitar, independentemente de contribuição à seguridade social, e tem por objetivos a proteção à velhice. Os filhos maiores têm o dever de ajudar e amparar os pais na velhice, carência ou enfermidade. E para fechar o conjunto de normas protetivas, foi determinado no artigo 230 que a família, a sociedade e o Estado têm o dever de amparar as pessoas idosas, assegurando sua participação na comunidade, defendendo sua dignidade e bem-estar, garantindo-lhes o direito à vida.

Percebe-se que o constituinte destacou a responsabilidade do Poder Público, sem, contudo, desconsiderar o elemento da família e sociedade no amparo à população idosa. Consagrando, assim, o princípio da solidariedade.

Seguindo a determinação constitucional, bem como a preocupação internacional, houve a edição da Lei no 8.842/94 - Lei da Política Nacional do Idoso, que tem por objetivo assegurar os direitos sociais aos idosos, criando condições para promover sua autonomia, integração e participação efetiva na sociedade.

Como síntese das garantias constitucionais no campo das políticas destinadas ao público idoso, foi promulgada a Lei, n. 8.742, de 7 de dezembro de 1993, Lei Orgânica da Assistência Social (LOAS), que reconheceu a pessoa idosa como detentora de atenção prioritária, tendo seu art. 2o estabelecido, (com redação dada pela Lei n. 12.435, de 6 de julho 
de 2011) dentre os objetivos da assistência social, "a garantia de um benefício mensal de um salário mínimo á pessoa portadora de deficiência e ao idoso que não possuir meios de prover a própria manutenção ou de tê-la provida por sua família".

Há também de se elencar aqui a Lei n. 8080/1990, Lei Orgânica de Saúde, asseguradora do direito universal e integral à saúde; em virtude desta, foi estabelecida, em 1999, a Política Nacional de Saúde do Idoso, com a Portaria Ministerial n. 1.395/1999, regulamentada pela Portaria n. 2.528 de outubro de 2006, que a renomeou como Política Nacional de Saúde da Pessoa Idosa, estabelecendo como uma de suas diretrizes a promoção do envelhecimento ativo e saudável, de acordo com as recomendações da Organização das Nações Unidas.

Para dar maior proteção e concretização aos direitos desse segmento da população, o legislador ordinário elaborou o Estatuto do Idoso que além de reafirmar o direito à vida, à segurança, à liberdade, à propriedade, a saúde, à educação, ao lazer, ao trabalho, entre outros,

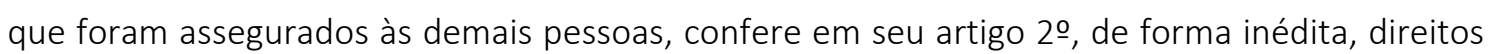
específicos e diferenciados os idosos. Desta forma, o idoso é titular de todos os direitos fundamentais, sem prejuízo da proteção integral que o estatuto confere.

Todavia, as pessoas idosas precisam se conscientizar de que esses direitos existem, autoridades e demais cidadãos devem agir no sentido de afirmá-los senão de nada terá adiantado todo o esforço para sua elaboração e vigência. A lei por si só, como se tem visto, não é capaz de mudar a realidade. Ela necessita da disposição de todos no sentido de cumpri-la. Assim, para uma maior efetivação de todos os direitos fundamentais das pessoas idosas, faz-se necessário que tanto a sociedade, como também a família e o Poder Público implementem políticas públicas a fim de se conferir a efetiva inclusão dessas pessoas em nossa comunidade.

\section{A EXCLUSÃO URBANA DO IDOSO}

Laranjeira (2010, p.763-770) destaca dois posicionamentos ideológicos conflitantes acerca do envelhecimento: o ageism, que engloba ideologias de marginalização e construção de estereótipos pejorativos acerca do envelhecimento; e o envelhecimento ativo, posicionamento da Organização Mundial da Saúde a partir de fins da década de 1990, construção que se refere à otimização de oportunidades de vida (saúde, participação e desenvolvimento multidimensional da pessoa) conforme seu envelhecimento).

No que tange ao ageism (que, segundo o autor, é relacionado ao positivismo moderno) (LARANJEIRA, 2010, p.765), este emerge na evolução de considerações sociais do velho: de uma 
Golden age pré-moderna, em que o idoso detém posições importantes no seio do grupo (a admiração do mais velho na família, por exemplo) à exclusão social (revelada no desprezo e no isolamento cada vez maiores). Essa exclusão, etapa extrema da marginalização, seria o reflexo de diversos processos sociais (e.g. industrialização, mudança dos modelos familiares, desmistificação da ancestralidade, educação das massas, emergência da tecnocracia, institucionalização da aposentadoria, etc.) - enfim, da secularização do poder nas dinâmicas sociais, o que aos poucos vai construindo uma imagem de declínio da produtividade e da eficiência relacionada à velhice (o que se revelaria nas imagens de incapacidade funcional, fragilidade e dependência frequentemente a ela associadas).

Já o envelhecimento ativo representa uma evolução cultural reflexa em relação a vários fatores - dentre os quais, a representatividade da população idosa (resultado do envelhecimento populacional), novas oportunidades de vida (que se dão em virtude de novas tecnologias de comunicação) e significativa melhoria da situação econômica da população idosa. Ademais, o desenvolvimento da tecnologia (principalmente cosmética, farmacêutica, de cirurgias plásticas, entre outras) vai aos poucos fazendo com que "o envelhecimento passe a ser um processo em aberto, negociável que pode ser retardado" (LARANJEIRA, 2010, p.767).

Também posicionamentos que apontam para possibilidades de empoderamento do indivíduo da terceira idade em relação à sociedade (possibilidade de uso de suas capacidades diferenciadas adquiridas ao longo da experiência em carreiras específicas, por exemplo) contribuem com a desconstrução da imagem negativa perpetrada durante boa parte dos séculos XIX e XX, levando as Nações Unidas a elencarem, em 1999 (Ano Internacional dos Idosos) diversos princípios atribuíveis ao idoso - dentre os quais: dignidade, autonomia, desenvolvimento pessoal, acesso aos cuidados básicos e participação ativa na comunidade todos esses fundados na cidadania, na emancipação e na pluralidade.

Ademais, conforme apontam Silva e Yazbek (2014), a América Latina, região onde se verificam as maiores desigualdades no mundo, tem enfrentado o problema do envelhecimento da população de modo bastante acentuado, o que tem levado pensadores (principalmente aqueles ligados à Cepal) a elaborar estudos e eventos vocacionados a pressionar governos da região a incorporarem e desenvolverem sistemas de proteção social aos idosos, incrementando assim o chamado Estado Social com medidas de consideração do risco social que afeta tais populações peculiares.

Diversos são os objetivos elencados para o enfrentamento do risco social que perpassa a pessoa idosa - sendo os principais "a preocupação com a garantia de níveis mínimos de 
qualidade de vida aos cidadãos associada a políticas de promoção do acesso a direitos universais e a serviços sociais condizentes com a dignidade humana" (SILVA; YAZBEK, 2014, p. 106).

No que concerne ao Brasil pós-Constituição de 1988, tem-se o desenvolvimento de legislações e programas específicos de proteção social ao idoso (mormente no que tange à seguridade social e à dignidade, elencada como fundamento da República). Sintetizando as garantias sociais constitucionais para o idoso, diversas leis foram promulgadas desde então.

Percebe-se, assim, um momento de evolução sistêmica em vários sistemas - ciência, economia, política, principalmente - com o estabelecimento de novos padrões de estabelecimento de expectativas acerca dos idosos. Trata-se, sem dúvida, da constatação de variação e seleção de novas formas de comunicação social acerca do idoso - contudo, é questionável qualquer assertiva acerca da estabilização desses padrões de modo efetivo no âmbito social como um todo (ou seja, nos sistemas mais significativos).

Primeiramente, deve-se apontar para os desafios impostos por raciocínios jurídicos pautados pelo utilitarismo (pensar os direitos fundamentais conforme uma moralidade embasada no somatório das realizações pessoais com vistas à garantia da "felicidade geral") ou pelo formalismo deontológico (considerar a igualdade formal, perante a lei, como tônica da jusfundamentalidade). Conforme apontam Rojas e Eckman (2011, p. 150), tanto o utilitarismo quanto a igualdade formal têm suas lógicas derrubadas em razão das diferenças e da complexidade apresentadas por uma população marcada por gerações diversas.

Contudo, a institucionalização da velhice pelo Estado - que, por meio de políticas públicas ao longo da história mais recente (a partir da Modernidade) passa a avocar para si o cuidado dos indesejados (loucos, abandonados, pobres, apenados, entre outros) - se revela um modo de continuidade de um modelo econômico baseado na força produtiva daqueles que se encontram economicamente ainda ativos. Some-se a isso o fato de que o esgotamento do Welfare State vem a reforçar uma "reprivatização da velhice", relegando seus cuidados aos cuidados da família ou de instituições de longa permanência (CAMARANO, 2008, p. 10-39).

Ademais, a própria colocação da velhice como questão social (ou seja, comunicar acerca da velhice como algo não apenas a ser questionado e analisado, mas também, como possuindo questões práticas a serem resolvidas) acaba sendo obstaculizada pelo envelhecimento natural. Conforme colocam Debert e Oliveira (2012, p. 196-213), os velhos não possuem meios sociais ou instrumentos de pressão pública - sendo que os representantes que se arrogam o poder de 
seus porta-vozes atualmente são experts gerontólogos (quando não apenas políticos com pretensões unicamente eleitoreiras).

A complexidade das comunicações acerca da velhice pelos próprios idosos se dá não apenas no que tange às suas diferenças em relações aos demais grupos sociais, mas também, no que concerne a diferenças internas: no dizer de Fernandes e Garcia (2010, p. 781-782), há diferenças na percepção e evocação do que é ser velho também entre os gêneros (homens e mulheres) ao se pronunciarem sobre sua condição. A velhice masculina amedronta em razão da expectativa do risco de dependência, de doença, de finitude e da inutilidade econômica decorrente da pecha de "aposentado". Já as mulheres expressam o temor não apenas da doença e da dependência, mas também, do abandono e da violência.

É notável, portanto, que sistemicamente o idoso é excluído das comunicações dos sistemas sociais, mesmo que várias menções políticas (mormente legislativas) e científicas sobre eles sejam feitas - pois são feitas sobre eles, muito raramente por eles. O envelhecimento é comunicado como paulatina exclusão até mesmo da parte dos próprios indivíduos que envelhecem, e os seus medos são medos da exclusão. Muitos comentários acerca dessa condição poderiam ainda ser tecidos aqui - porém, faz-se importante passar a discutir essa condição de excluído não apenas dos sistemas sociais, mas também, do espaço urbano.

Conforme apontam Véras e Felix (2016, p. 441-459), cerca de 84\% dos idosos brasileiros vivem nas áreas mais pobres e precárias das cidades - o que demonstra que, além de serem segregados do restante da população em razão do envelhecimento natural dos seus corpos e mentes, também o são em razão do declínio de sua condição econômica (perda da capacidade produtiva, recebimento de benefícios de aposentadoria parcos, etc.). Aumenta a complexidade dessa situação o fato de que comunicações econômicas irritam o sistema político em busca de uma postergação da aposentadoria diante de um cenário de maior longevidade aparentemente sustentado por comunicações científicas. Também comunicações relacionadas a um "envelhecimento ativo", pautadas em programas econômicos, corrobora com essa situação, pois ao mesmo tempo: i) incentiva a transformar num dever aquilo que seria parte da liberdade de escolha do indivíduo, em seara jurídico-moral (DEBERT, 1999, p. 162); ii) despe de toda responsabilidade o Estado em relação aos idosos necessitados (DEBERT, 1999, p. 191).

Falar de um envelhecimento ativo na cidade como opção de maioria (ou, pelo menos, de parte considerável) da população idosa no Brasil soa contraditório. Sequer em países onde o Estado de Bem-Estar Social se desenvolveu adequadamente se verifica um envelhecimento com boas condições de saúde (física e financeira) da Terceira Idade - e, no Brasil, onde 63,7\% dos 
idosos são chefes de família, 51,9\% auferem renda inferior a um salário mínimo e possuem escolaridade média de 3,9 anos de estudos (INSTITUTO BRASILEIRO DE GEOGRAFIA E ESTATÍSTICA, 2018).

A noção de envelhecimento ativo tem servido de base para iniciativas comunitárias e políticas de inclusão do idoso na cidade em várias partes do mundo e do Brasil. Graeff (2014) elenca várias delas, sendo as mais significativas, no exterior: i) a difusão do programa "Cidade Amiga do Idoso", da Organização Mundial de Saúde, e que foi amplamente efetivada no Canadá e na França; ii) a instalação da Rede Francófona de Cidades Amigas do Idoso; iii) a Rede Iberoamericana de Cidades Amigas do Idoso. E no Brasil, as seguintes são tidas como exemplificativas: i) a edição do Decreto 8.114/2013 (BRASIL, 2013), o qual estabeleceu o Compromisso Nacional para o Envelhecimento Ativo e institui Comissão Interministerial para monitorar e avaliar ações em seu âmbito e promover a articulação de órgãos e entidades públicos envolvidos em sua implementação; ii) o Decreto 58.047/2012 do Estado de São Paulo (ESTADO DE SÃO PAULO, 2014), o qual instituiu o Programa Estadual "São Paulo Amigo do Idoso", e o "Selo Amigo do Idoso"; iii), dentre outros.

É notável, portanto, a necessidade de se analisar não apenas o idoso como excluído da sociedade, mas também, como excluído do espaço urbano - e essa análise deve também pautar as suas estratégias de inclusão. Quando se trata da cidade, é notável que, em termos sistêmicos, este é um espaço físico, constituído como ambiente dos sistemas sociais - mas, sendo criação humana (o qual se vale, notadamente, das comunicações para a consecução de suas atividades), recebe irritações das comunicações sociais (e, em via oposta-recíproca, também a observação do espaço pelos sistemas sociais pode ocasionar reflexos e aprendizados nestes). O direito, como sistema social, ao observar o urbano, deve interiorizar a noção de ambiência para melhor atender a direitos sociais dos idosos na cidade (em outras palavras, sua inclusão no manancial comunicativo jurídico) (GRAEFF, 2014, p. 614).

A noção de ambiência, transdisciplinar (eis que envolve conhecimentos das Ciências da Saúde, Agrárias, da Proteção Laboral, Gerontologia, Arquitetura, dentre outras), implica, conforme explana Tixier (2007, p. 10), uma multitude de pilares epistemológicos, os quais podem ser resumidos da seguinte forma: i) sensibilidade ao mundo; ii) multidisciplinariedade abordando espaços sociais, construídos e sensíveis; iii) "trans-escala" (ou seja, pode se referir tanto a espaços ordinários quanto a espaços comuns); iv) centralização do projeto na experiência do usuário (seja para o estudo, seja para a concepção de um espaço). Nesse sentido, pensar em ambiências é pensar a multidimensionalidade de sensações (térmicas, 
acústicas, temporais, físicas, etc.), a diversidade de ocupantes e sensorial (GRAEFF, 2014, p. 616).

No que tange aos direitos fundamentais dos idosos relacionados às ambiências urbanas, tem-se que essa conceituação relacional tem relação direta para com a sua saúde (pois a qualidade do ambiente afeta não apenas o modo pelo qual o idoso se relaciona com ele, mas também, a salubridade dessa relação pode afetar o seu bem-estar, por exemplo); o seu direito ao lazer e à participação da vida em comunidade também está diretamente relacionado com o modo pelo qual se relaciona com as ambiências urbanas (proporcionando-lhes mobilidade, possibilidades comunicativas, etc.); outro exemplo é o direito à segurança (um espaço considerado inseguro por falta de policiamento, de iluminação ou de ergonomia para o movimento peculiar do idoso pode fazer com que determinadas ambiências não sejam por ele frequentado, resultando em fator de isolamento).

O fato inexpugnável é que não apenas a população está envelhecendo (no Brasil e no mundo), mas também, que cada vez mais, se urbaniza: no ano de 2005, cerca de 49\% (quarenta e nove por cento) da população mundial vive em zonas urbanas, sendo a previsão de que, até 2030, essa população atinja o índice de 60\% (sessenta por cento) (DEPARTMENT OF ECONOMICS AND SOCIAL AFFAIRS, 2006). Há, portanto, um duplo desafio: não apenas acomodar a maior parte da população no ambiente urbano (considerando-se não apenas o seu espaço físico, mas também suas ambiências, interações, comunicações, organizações, etc.), mas também considerar que essa população estará maior em níveis globais e envelhecida biologicamente.

Pessoas envelhecidas necessitam de estruturas que facilitem a sua mobilidade entendida, aqui, como acesso a serviços públicos essenciais para o seu bem-estar global (habitação digna, serviços sociais e de saúde), sendo dado destaque aos serviços de transporte público e aos aparelhamentos urbanos para a circulação de pedestres, tendo em vista que, na medida em que a pessoa envelhece, não apenas sua capacidade visual e psicomotora decai (fato pelo qual as legislações vedam a licença para dirigir a pessoas que atingem determinada idade e capacidades essenciais para a direção, por exemplo), mas também sua renda (é notória a diminuição no poder de compra dos aposentados e beneficiários das Previdências em razão da idade). Todavia, conforme apontam Santinha e Marques (2013, p. 396), “[...] a simples existência de espaços desprovidos de constrangimentos físicos à mobilidade é condição necessária mas não suficiente para induzir o deslocamento dos cidadãos". As políticas públicas para incremento e desenvolvimento da mobilidade de pessoas idosas deve levar em 
consideração distâncias, padrões de ocupação/uso do território e condições de mobilidade dos pedestres e fatores que provocam o deslocamento no espaço urbano.

Apesar de todas essas necessidades decorrentes de um período tão complexo quanto o envelhecimento, o Brasil apresenta características peculiares e deletérias no seu trânsito, que vêm a afetar a qualidade do tráfego de veículos individualizados e coletivos: sistema de transporte defasado (principalmente no que tange às tecnologias antigas de suspensão e conforto), congestionamentos frequentes (causados muito em razão da elevada quantidade de veículos individualizados), além de ser um dos trânsitos mais violentos do mundo; e, no que tange às dificuldades para a população idosa no transporte público, há fatores obliterantes ao acesso tais como altura dos degraus nos veículos, dificuldade de comunicação em razão do atendimento aos passageiros ser feito, na maioria das vezes, pelos próprios motoristas , ocupação indiscriminada de bancos prioritários e frequentes acidentes (BLANCO et al., 2014, p. 149).

Como estratégia (talvez paliativa, mas sem dúvida importante) de incremento de acessibilidade, crianças de até quatro anos de idade e idosos com idade igual ou superior a sessenta e cinco anos têm o direito à passagem gratuita (ou parcialmente) em viagens urbanas em transportes coletivos. Contudo, não são fundos públicos que subsidiam essas diferenças de passagens, mas sim, os pagamentos provenientes dos demais passageiros, que dispendem do valor integral nas suas passagens. Isso gera uma situação economicamente desfavorável em razão do próprio envelhecimento populacional: conforme apontam Pereira et al. (2015, p. 115 e ss.), até 2050, na Zona Metropolitana de São Paulo (maior conglomerado urbano brasileiro), por exemplo, se forem mantidas as mesmas estratégias de cálculo e financiamento das passagens de idosos nos transportes públicos, haverá um incremento de cerca de 21\% (vinte e um por cento) no valor das passagens pelo simples acesso gratuito a uma população cujo número cresce espantosamente.

É de se apresentar, como exemplo pesquisado de descaso para com a mobilidade do pedestre da terceira idade (o que diz respeito, diretamente, à sua liberdade de ir e vir), a pesquisa de Soares Junior et al. (2015, p. 9-15), que retratam o descaso do Poder Público, da população e dos profissionais da arquitetura e do urbanismo com a qualidade das calçadas na cidade de Maringá/PR. Sua constatação é de que não apenas nas áreas centrais da cidade os passeios públicos desrespeitam normas técnicas que prescrevem padrões de qualidade, mas também (e principalmente), nos bairros - onde os proprietários dos imóveis a tratam com descaso. 
Trata-se, contudo, não de buscar um responsável pelo fato deletério, mas sim, de analisar que se trata de um complexo de responsabilidades: o cidadão deve contribuir (não apenas com tributação, mas com atitude proativa no que tange ao respeito da mobilidade dos transeuntes, vulneráveis ou não); o Poder Público, atribuir padrões e fiscalizar condutas; e os profissionais de arquitetura e urbanismo, de empreender esforços não apenas em relação à construção dos prédios, mas também, das facilidades anexas e paralelas.

Também é ilustrativo desse descaso a pesquisa de Freire Júnior et al. (2013, p. 541558), o qual trouxe à tona que a maioria dos idosos da cidade de Caratinga, Estado de Minas Gerais, se locomove a pé (cerca de 55,3\%). Ademais, seus problemas mais frequentes de mobilidade urbana podem ser descritos como obstáculos nas calçadas (66,3\%), aglomeração de pessoas $(63,5 \%)$, dificuldades para atravessar a rua $(55,3 \%)$ e quedas no centro da cidade $(33 \%)$. Isso leva a pensar que, para além das vulnerabilidades relacionadas ao envelhecimento biológico (desde a consciência das limitações do próprio corpo até a diminuição da renda causada pela aposentadoria), o próprio espaço construído se torna um empecilho para a maioria da população idosa.

\section{CONSIDERAÇÕES FINAIS}

Após todo o exposto anteriormente, cabem algumas considerações a título de encerramento do presente trabalho. Inicialmente, é de se salientar que a urbanização atinge não apenas o espaço e as interações urbanas, mas também, com ela, se organizam as relações sociais no campo em direção ao centro urbano. Com isso, o centro urbano não pode mais ser entendido como isolado espacialmente, mas sim, comunicativamente relacionado para com outros centros urbanos (que, por sua vez, estabelecem comunicações político-econômicas para com a zona rural), configurando-se, assim, uma grande rede comunicacional do tipo urbanourbano; urbano-rural; etc.

A diferenciação funcional da sociedade passa a exigir um raciocínio baseado na inclusão e na exclusão das pessoas dos sistemas comunicativos (Direito, Economia, Política, Ciência, Educação, Saúde, etc.) - ao contrário das sociedades tradicionais, as quais realizavam a inclusão (ou exclusão) mediante a lógica das famílias (as quais, por sua vez, eram distribuídas em estratos). Com o advento da modernidade, contudo, as pessoas passam a ser excluídas de modo muito mais paradoxal (para além das famílias e estratos): em que pese os sistemas funcionais pressuponham a inclusão de todos os seres humanos (em suas formulações racionais 
e abstratas), excluem, de fato, pessoas que não atendam aos seus requisitos (registros, institucionalização, atenção a certas regras e praxes, etc.), sendo que um tipo de exclusão leva a outra(s). Portanto, no que tange à exclusão, a sociedade funcionalmente diferenciada é extremamente integrada, sendo que os valores basilares da modernidade (liberdade, igualdade, felicidade e satisfação individual, etc.) tão-somente encobrem a preservação de uma ilusão de inocência.

Vários são os grupos de pessoas que se encontram, de uma forma ou outra, excluídos de algum (senão de vários, concomitantemente) sistemas comunicativos globais: miseráveis, imigrantes, desempregados, perseguidos (religiosos, étnicos, políticos), pessoas com deficiência, etc. Algumas formas de exclusão se dão por ação (perseguir, barrar, interditar, destruir, rotular, etc.); outras, por omissão (não comunicar política ou dogmaticamente direitos e/ou a existência de tais pessoas). Mas também há a exclusão relacionada às características sociais/relacionais de certos grupos (incapazes de consumir conforme certos padrões econômicos; patriotas de determinadas nacionalidades; indivíduos cujos comportamentos sejam considerados fora de padrão, etc.), e outros, ainda, que o são em relação a características psíquicas e biológicas consideradas pejorativas (concernentes a seu gênero, idade, condição genética e incapacidades). Todas essas formas de exclusão (mas especialmente a última aqui enumerada) atingem os idosos, ao longo da história.

Trata-se, contudo, não de buscar um responsável pela exclusão, mas sim, de analisar que se trata de um complexo de responsabilidades: o cidadão deve contribuir (não apenas com tributação, mas com atitude proativa no que tange ao respeito da mobilidade dos transeuntes, vulneráveis ou não); o Poder Público, atribuir padrões e fiscalizar condutas; e os profissionais de arquitetura e urbanismo, de empreender esforços não apenas em relação à construção dos prédios, mas também, das facilidades anexas e paralelas.

\section{REFERÊNCIAS}

AGAMBEN, Giorgio. Homo sacer: o poder soberano e a vida nua. Belo Horizonte: Ed. UFMG, 2002.

BEAUVOIR, Simone de. A velhice. Tradução de Maria Helena Franco Martins. Rio de Janeiro: Nova Fronteira, 1990.

BLANCO, Priscilla Hellen Martinez; CASTILHO, Mario Moreira; BALNCO, Thiago Henrique Martinez; CORTEZ, Lucia Elaine Ranieri. Mobilidade urbana no contexto do idoso. Revista Cesumar Ciências Humanas e Sociais Aplicadas, v.19, n.1, 2014, p. 143-155. 
BOBBIO, Norberto. A era dos direitos. Tradução de Carlos Nelson Coutinho. Rio de Janeiro: Campus, 1992.

BRAGA, Rogério Piccino; LEITE, Flávia Piva Almeida; BAHIA, Claudio José Amaral. Garantias fundamentais da pessoa idosa: uma revolução por direitos rumo à inclusão. Constituição, Economia e Desenvolvimento: Revista da Academia Brasileira de Direito Constitucional. Curitiba, 2017, v. 9, n. 17, Jul.-Dez. p. 431-450.

BRAGA, Pérola; VIANNA, Melissa. Curso de direito do idoso. São Paulo: Atlas, 2011

BRASIL. Decreto no 8.114, de 30 de setembro de 2013. Estabelece o Compromisso Nacional para o Envelhecimento Ativo e institui Comissão Interministerial para monitorar e avaliar ações em seu âmbito e promover a articulação de órgãos e entidades públicos envolvidos em sua implementação. Disponível em: <http://www.planalto.gov.br/ccivil_03/_Ato20112014/2013/Decreto/D8114.htm>. Acesso em 12 abr 2018.

BRASIL. Presidência da República. Secretaria de Direitos Humanos. Dados sobre o envelhecimento no Brasil. Disponível em: <http://www.sdh.gov.br/assuntos/pessoaidosa/dados-estatisticos/DadossobreoenvelhecimentonoBrasil.pdf>. Acesso em 03 maio 2018.

CAMARANO, Ana Amélia. Cuidados de longa duração para a população idosa? Família ou instituição de longa permanência? Sinais Sociais, v. 3, n. 7, 2008, p. 10-39.

CÍCERO, Marco Túlio. Saber envelhecer- Seguido de A amizade. Tradução de Paulo Neves. Porto Alegre: L \& PM, 2001.

CONFÚCIO. Vida e doutrina. Os analectos. Tradução de MúcioPorphyrio Ferreira. São Paulo: Pensamento, 1999.

CRESCENZO, Luciano de. História da filosofia grega - a partir de Sócrates. Lisboa: Presença, 1988.

DEBERT, Guita Grin. A reinvenção da velhice: socialização e processos de reprivatização do envelhecimento. São Paulo, Edusp/Fapesp, 1999.

DEBERT, Guita Grin; OLIVEIRA, Amanda Marques. A feminização da violência contra o idoso e as delegacias de polícia. Mediações, v. 17, n. 2, 2012, p. 196-213.

DEPARTMENT OF ECONOMICS AND SOCIAL AFFAIRS.Population Division.World urbanization prospects: the 2005 revision. New York: United Nations, 2006.

DIMOULIS, Dimitri; MARTINS, Leonardo. Teoria Geral dos Direitos Fundamentais. São Paulo: Editora Revista dos Tribunais, 2007.

ESTADO DE SÃO PAULO. Decreto no 58.047, de 15 de maio de 2012. Institui o Programa Estadual "São Paulo Amigo do Idoso", e o "Selo Amigo do Idoso", e dá providências correlatas. 2014. Disponível em: <https://www.al.sp.gov.br/norma/?id=167039>. Acesso em 12 abr 2018. 
FERNANDES, Maria das Graças Melo; GARCIA, Loreley Gomes. O Sentido da Velhice para Homens e Mulheres Idosos. Saúde e Sociedade, v.19, n.4, 2010, p.771-783.

FORNASIER, Mateus de Oliveira. Sociedade mundial complexa e teoria das fontes do Direito: prolegômenos para uma revisão teórica in BEDIN, Gilmar Antonio; TEIXEIRA, João Paulo Allain (Coord.). Teorias do direito [Recurso eletrônico on-line]. Florianópolis: CONPEDI, 2015a. p. 404 a $4027 . \quad$ Disponível em: $<$ https://www.conpedi.org.br/publicacoes/c178h0tg/bx47d9jb/gz4EhUodaybTjZ2A.pdf>. Acesso em 03 jul 2018.

FORNASIER, Mateus de Oliveira. Transdisciplinaridade e teoria dos sistemas autopoiéticos: convergências interessantes para a observação jurídica da complexidade. Cadernos de Pesquisa Interdisciplinar em Ciências Humanas, v. 16, n. 109, jul./dez. 2015b.

FORNASIER, Mateus de Oliveira. LEITE, Flavia Piva Almeida. Direitos fundamentais à acessibilidade e à mobilidade urbanas da pessoa com deficiência: uma abordagem sistêmicoautopoiética. Revista de Direito da Cidade, v. 08, n. 3, 2016, p.908-933.

FREIRE JUNIOR, Renato Campos; ARÊAS, Guilherme Peixoto Tinoco; ARÊAS, Fernando Zanela da Silva; BARBOSA, Luis Guilherme. Estudo da acessibilidade de idosos ao centro da cidade de Caratinga, MG. Revista Brasileira de Geriatria e Gerontologia, v. 16, n. 3, 2013, p. 541-558.

GRAEFF, Bibiana. A pertinência da noção de ambiências urbanas para o tema dos direitos dos idosos: perspectivas brasileiras. Revista Brasileira de Geriatria e Gerontologia, Rio de Janeiro, v. 17, n. 3, 2014, p. 611-625.

GUIMARÃES, Virginia Totti. Direito à cidade e direitos na cidade: integrando as perspectivas social, política e jurídica. Revista de Direito da Cidade, v. 09, n. 2, 2017, p. 626-665.

GÜNTHER, Gotthard. Life as Poly-Contexturality.Vorkender, [S. I.], fev. 2004. Disponível em: <http://www.vordenker.de/ggphilosophy/gg_life_as_polycontexturality.pdf >. Acesso em: 19 set. 2013.

HAYFLICK, Leonard. How and why we age. Experimental Gerontology, v. 33, n. 7/8, p. 639-653, 1998.

INSTITUTO BRASILEIRO DE GEOGRAFIA E ESTATísTICA (IBGE). Censo Demográfico 2010, Rio de Janeiro, 2011. Disponível em: http://www.ibge.gov.br/home/estatistica/populacao/censo2010/. Acesso em 10 abr 2018.

LARANJEIRA, Carlos António. "Velhos são os Trapos": do positivismo clássico à nova era. Saúde e Sociedade. São Paulo, v.19, n.4, 2010, p.763-770.

LEFEBVRE, Henri. A revolução urbana. Belo Horizonte: Ed. UFMG, 2004.

LEFEBVRE, Henri. Espacio y politica: el derecho a la ciudad. Barcelona: Peninsula, 1976.

LEITE, Flávia Piva Almeida Leite. Cidades acessíveis. São Paulo: SRS, 2012

Revista de Direito da Cidade, vol. 10, no 3. ISSN 2317-7721 pp. 2073-2105 
LEITE, Flavia Piva Almeida. O Direito Fundamental ao acesso à internet pelos usuários com deficiência: marco civil da internet in FIORILLO, Celso Antonio Pacheco; MARTINEZ, Regina Célia (Org.). Os 20 anos da internet no Brasil, seus reflexos no meio ambiente digital e sua tutela jurídica na sociedade de informação [recurso digital], 2015, p. 148-172. Disponível em: <file:///D:/Documentos/desktop/34043-115190-4-RV.pdf>. Acesso em 03 jul 2018.

LUHMANN, Niklas. Globalization or world society: how to conceive of modern society? International Review of Sociology, [S. I.], v. 7 n. 1, p. 67-79, mar./1997.

LUHMANN, Niklas. Introdução à Teoria dos Sistemas. Trad. Ana Cristina Arantes Nasser. 2a edição. Petrópolis: Editora Vozes, 2010.

LUHMANN, Niklas. La ciencia de lasociedad. Trad. Silvia Pappe, BrunhildeErker, Luis Felipe Segura; sob direção de Javier Torres Nafarrate. México: Universidad Iberoamericana; ITESO; Anthropos, 1996a.

LUHMANN, Niklas. La sociedad de la sociedad. Tradução de Javier Torres Nafarrate. México: Herder, 2007.

LUHMANN, Niklas. Law as a social system.Trad. Klaus A. Ziegert. New York: Oxford University Press, 2004.

LUHMANN, Niklas. O amor como paixão: para a codificação da intimidade. Tradução de Fernando Ribeiro. Lisboa: Difel, 1991.

NEVES, Marcelo. A força simbólica dos direitos humanos. Revista Eletrônica de Direito do Estado, n. 4. Salvador, Bahia, Brasil: outubro/novembro/dezembro de 2005.

NEVES, Marcelo. Transconstitucionalismo. São Paulo: WMF Martins Fontes, 2009.

NUÑEZ, Ana Estela. Del Derecho a la Ciudad, al Derecho al Espacio Diferencial. Revista de Direito da Cidade, vol.06, no 01, 2014, p. 90-110.

MAGALHÃES, Juliana Neuenschwander. O paradoxo dos direitos humanos. Revista da Faculdade de Direito - UFPR, Curitiba, n.47, p.29-64, 2008.

ORGANIZAÇÃO DAS NAÇÕES UNIDAS. Fundo de População (UNFPA). Envelhecimento no Século XXI: Celebração e Desafio [recurso eletrônico]. Nova York, Londres: Fundo de População das Nações Unidas (UNFPA), HelpAge International, 2012. Disponível em: $<$ https://www.unfpa.org/sites/default/files/pub-pdf/Portuguese-Exec-Summary_0.pdf >. Acesso em 04 jul 2018.

PEREIRA, Rafael Henrique Moraes; CARVALHO, Carlos Henrique Ribeiro de; SOUZA, Pedro Herculano G. Ferreira de; CAMARANO, Ana Amelia. Envelhecimento populacional, gratuidades no transporte público e seus efeitos sobre as tarifas na Região Metropolitana de São Paulo. Revista Brasileira de Estudos Populacionais, v. 32, n.1, 2015, p. 101-120.

PHILIPPOPOULOS-MIHALOPOULOS, Andreas. Absent Environments:Theorising Environmental Law and the City. London: Routledge, 2007 
PLATÃO. A república. Tradução de Elza Moreira Marcelina. Brasília: UnB, 1985. Livro 7.

RAMOS, Paulo Roberto Barbosa. Curso de direito do idoso. São Paulo: Saraiva, 2014.

ROGOWSKI, Ralf. Reflexive Labour Law in the World Society.Cheltenham; Northampton: Elgar, 2015.

ROJAS, Viviane Filgueiras; EKMAN, Nanci Claudete. Direito fundamental ao envelhecimento inclusivo. Direito e Práxis, v. 02, n .01, 2011, p. 143-158.

SANTINHA, Gonçalo; MARQUES, Sara. Repensando o fenômeno do envelhecimento na agenda política das cidades: a importância da promoção da mobilidade de pedestres. Revista Brasileira de Geriatria e Gerontologia, v. 16, n. 2, 2013, p. 393-400.

SANTOS, Silvana Sidney Costa. Envelhecimento: visão de filósofos da antiguidade oriental e ocidental. Revista RENE. Fortaleza, v. 2, n. 1, p. 88-94, jul./dez./2001.

SCHMITT, Carl. Teoria de la constitución. 1ạ ed. Madrid: Alianza, 1992.

SCHWARTZ, Germano. O humano e os humanos nos direitos humanos. Animais, Pacha Mama e altas tecnologias. In SCHWARTZ, Germano (Org.). Juridicização das esferas e fragmentação do direito na sociedade contemporânea. Porto Alegre: Livraria do Advogado Editora, 2012, p. 209228.

SÉGUIN, Élida. O idoso aqui e agora. Rio de Janeiro: Lumen Juris, 2001.

SENNET, Richard. A carne e a pedra. Tradução Marco Aarão Reis. Rio de Janeiro:BestBolso, 2008.

SILVA, Maria do Rosário de Fátima e; YAZBEK, Maria Carmelita. Proteção social aos idosos: concepções, diretrizes e reconhecimento de direitos na América Latina e no Brasil. Revista Katálysis, Florianópolis, v. 17, n. 1, p. 102-110, jan./jun. 2014.

SOARES JUNIOR, Waldir Silva; MOURA, Guilherme Ribeiro de; SKURA, Ivania; VELHO, Ana Paula Machado. Análise da qualidade das calçadas públicas de Maringá: garantindo o direito de ir e vir do idoso no ambiente urbano. Universitas: Arquitetura e Comunicação Social, v. 12, n. 1, 2015, p. 9-15.

TEUBNER, Gunther. The anonymous matrix: Human Rights Violations by 'Private' Transnational Actors. Modern Law Review, [S. I.], v. 69, n. 3, p. 327-367, 2006.

VÉRAS, Maura Pardini Bicudo; FELIX, Jorge. Questão urbana e envelhecimento populacional: breves conexões entre o direito à cidade e o idoso no mercado de trabalho. Cadernos Metropolitanos, v. 18, n. 36, 2016, p. 441-459.

TIXIER, Nicolas. L'usagedesambiances. Culture et Recherche, n. 113, 2007, p. 10-11.

Trabalho enviado em 03 de maio de 2018. 
Aceito em 24 de julho de 2018. 